\title{
Protective effect of Thymus quinquecostatus extracts UVB-induced matrix metalloproteinase-1 via suppressing MAPKs phosphorylation in human keratinocyte
}

\author{
Hana Jung' ${ }^{1}$ Hyun Ju Jeong ${ }^{2}$ Kyounghee Shin $^{3}$ - Yung Sun Kim² \\ Jae Heon Moon ${ }^{3}$. Tae Hoon Lee ${ }^{1}$ (D)
}

\section{사람의 각질세포에서 UVB 유도에 따른 MMP-1의 발현 조절과 MAPKs 인산화에 타임 추출물이 미치는 효과}

정하나 $^{1} \cdot$ 정현주 $^{2} \cdot$ 신경희 $^{3} \cdot$ 김영선 $^{2} \cdot$ 문제현 $^{3} \cdot$ 이태훈 $^{1}$

Received: 1 November 2018 / Accepted: 22 November 2018 / Published Online: 31 December 2018

(C) The Korean Society for Applied Biological Chemistry 2018

\begin{abstract}
Ultraviolet rays are electromagnetic waves with a shorter wavelength than visible light, and ultraviolet rays that pass through the ozone layer are the main cause of skin aging. Chronic exposure of skin tissue to ultraviolet light activates the Mitogenactivated Protein Kinases (MAPKs) signaling pathways in human keratinocytes, resulting in increased production of matrix metalloproteinases (MMPs). In this study, we investigated the herbal extracts from Jeju Island on the anti-aging effect in human keratinocytes (HaCaTs) by ultraviolet stimulation. We examined that herb extract from Jeju Island were decreased in anti-aging activity on measuring the level of MMP-1 gene and protein expression in ultraviolet-induced keratinocytes. As a result, it was confirmed that Thymus quinquecostatus extract (TQE) significantly reduced the expression of MMP-1 in a dose-dependent manner by
\end{abstract}

Tae Hoon Lee $(\bowtie)$

E-mail: thlee@khu.ac.kr

${ }^{1}$ Department of Applied Chemistry, Kyung Hee University, Yongin 17410 , Republic of Korea

${ }^{2}$ Agricultural Corporation JEJUWOODA Co., Ltd, JeJu 63166, Republic of Korea

${ }^{3}$ Nature in Lab.Inc, Euwang 16071, Republic of Korea

This is an Open Access article distributed under the terms of the Creative Commons Attribution Non-Commercial License (http://creativecommons. org/licenses/by-nc/3.0/) which permits unrestricted non-commercial use, distribution, and reproduction in any medium, provided the original work is properly cited.
UV irradiated HaCaTs. According to our data, TQE significantly attenuated UV-induced phosphorylation of the MAPKs signaling elements ERK1/2, JNK1/2 and p38 proteins. These results suggest that the MAPKs pathway may contribute to the inhibitory effect of TQE on UV-induced MMP-1 production in human keratinocytes. Our results suggest that TQE may be a protective agent against skin aging by preventing UV-induced MMP-1 production.

Keywords Human Keratinocytes - Matrix metalloproteinases · Mitogen-activated protein kinase - Thymus quinquecostatus extract · Ultraviolet-B

\section{서 론}

피부 노화는 다음과 같이 크게 두 종류로 나눌 수 있다. 먼저, 내인성 노화 (intrinsic aging)로 알려져 있는 자연 노화 현상은 피부세포 노화에 따른 현상을 말한다. 각화 주기에 따라 오래 된 피부 세포는 각질 층으로 분화 하여 더 이상 역할을 담당하 지 못하게 되고 그 결과 진피 및 피하 층이 위축 되어 표피 조 직 주변에 존재 하는 collagen 및 fibronectin과 같은 extracellular matrix 가 기능을 하지 못하게 되는 것을 의미 한다[1]. 두 번 째는 광노화 (photoaging)로서 오랫동안 햇빛에 노출된 얼굴, 손 등, 목뒤 등의 피부에 서 관찰되는 노화현상을 말하는 것으로 자외선 (ultraviolet)은 광노화를 유발 하는 주요 원인이다[2]. 자 외선 스펙트럼은 UV-A (320-400 nm)와 UV-B (290-320 nm)로 
구분 되는데 특히, UV-B의 경우 인간의 피부에 산화 스트레스 를 유발 하여 일시적이고 지속적인 유전적 손상, 활성화 인자 의 증가 및 matrix metallopretenase (MMP)와 같은 노화 인자 의 발현 증가를 가져 올 수 있다[3]. 광 노화는 미세하고 거친 주름, 색소 침착 및 잔주름, 피부건조증, 탄력 감소 등을 들 수 있다[4]. UVB에 노출되면 피부노화를 촉진 시키는 콜라게네이 즈 (Collagenase)의 일종인 MMP 단백질의 발현이 증가하며, MMP 발현 증가로 인한 피부 진피를 구성하는 주요 단백질인 콜라겐을 분해하거나 생성을 감소 시킨다. MMP 발현의 억제 는 콜라겐 대사의 조절과 콜라겐 생성에 많은 영향을 미친다[57]. MMP는 MMP-1, MMP-3 및 MMP-9를 포함하고 특히 Interstitial collagenase 라고도 알려진 MMP-1은 주로 진피에서 가장 풍부한 구조 단백질 인 피부 type 1 collagen의 분해를 담 당한다[8]. 특히, MMP-1은 콜라겐의 특정 부위에 작용하여 콜 라겐을 두 조각으로 자르게 되는데, MMP-1을 콜라겐 분해 효 소라 부르며, 콜라겐 분해 효소는 자외선 자극에 따라 $\mathrm{MEK} /$ $\mathrm{MAPK}$ 인산화 기전을 통하여 MMP-1과 같은 단백질의 전사가 일어나는 것으로 알려져 있다[9]. UVB 자극은 ERK1/2, JNK 및 $\mathrm{p} 38$ kinase의 인산화를 활성화시키고, 이들 활성화 된 MAP kinase는 NF-kB 전사 인자의 중요한 subunit인 p65 및 p50 단 백질의 인산화를 촉진 하여 핵내로 translocation 되는 전사 인 자의 양을 증가시킨다. 따라서, 활성화 되어 핵내로 translocation 된 $\mathrm{NF}-\mathrm{kB}$ 는 $\mathrm{MMP}-1$ 과 같은 단백질의 전사를 촉진하여 collagen 분해를 야기 한다[10,11].

Thymus quinquecostatus는 고대 그리스인과 로마인이 약용 이 외에 알코올과 치즈를 맛보고 피부를 정화하며 신경을 진정시 키는 데 사용되는 살균성 에센셜 오일을 포함하고 있으며, 자 생 Thymus quinquecostatus의 경우 항균 활성을 나타낸다고 보 고 되었다[12]. 또한, Thymus quinquecostatus 에서 추출한 Thymol은 chang cell에서 유도되는 산화적 스트레스 감소 하여 세포의 사멸을 막는 효과가 있다고 보고 되었다[13]. 본 연구에 서는 제주의 천연 소재인 Thymus quinquecostatus의 추출물 (TQE)을 이용하여 각질세포에서 UVB에 의한 MMP-1의 발현 을 억제하고, 콜라겐 생성 효능에 변화를 확인하고자 하였다. 이를 위해 추출물의 세포 독성과 주름개선 효능과 다양한 피부 질환에 관여하는 $\mathrm{MAPKs}$ 의 인산화 신호전달체계에 미치는 영 향을 확인하고 천연물 소재에 의한 소재 개발의 가능성과 기능 성 원료를 위한 기초 자료로 활용하고자 하였다.

\section{재료 및 방법}

\section{추출물의 제조}

본 연구의 실험에 사용된 허브 소재는 (주)제주 우다(제주도, 서 귀포시)에서 재배하였고, 추출 방법은 $70 \%$ 에탄올을 사용하여 3 회 추출 하였으며 1 일 동안 추출한 내용물을 여과지에 여과 한 다음 evaporator (EYELA, Tokyo, Japan)를 이용하여 40 ${ }^{\circ} \mathrm{C}$ 에서 증발 시킨 다음 동결 건조기(HY Science, Incheon, $\mathrm{Korea})$ 에서 동결 건조하여 추출물을 제공 받았다. 동결 건조 된 추출물은 dimethyl sulfoxide에 $100 \mathrm{mg} / \mathrm{mL}$ 로 용해 한 후 0.20 $\mu \mathrm{m}$ syringe filter로 여과하여 농도에 맞게 희석하여 사용하였다.

\section{세포 배양}

HacaT cell 한국 세포 주 은행(KCLB, Seoul, Korea)에서 분양 받았으며, $1 \%$ penicillin-streptomycin과 $10 \% \mathrm{FBS}$ 를 포함하는 DMEM (Welgen, Seoul, Korea)배지를 사용하였다. 세포는 $37^{\circ} \mathrm{C}, 5 \% \mathrm{CO}_{2}$ 의 환경에서 배양하였다.

\section{Cell viability 측정}

세포 생존율 측정은 MTT assay를 사용하여 측정하였다. 96 well plate에 $1 \times 10^{4}$ cells/well의 HacaT 세포를 분주하고 24 시간 이상 안정화 단계를 거쳤다. 세포 안정화가 끝난 다음 성장 배 지를 재거하고 혈청이 제거된 배지에 시료를 농도 별 $(0,10,20$, $50,100,200,500,1000 \mu \mathrm{g} / \mathrm{mL}$ )로 희석하여 18 시간 동안 처리 한 다음 각 well당 $10 \mu \mathrm{L}$ 의 MTT solution을 첨가하여 $37^{\circ} \mathrm{C}$, $5 \% \mathrm{CO}_{2}$ 배양기에서 30 분에서 최대 2시간 동안 반응시킨 후, microplate reader를 이용하여 $450 \mathrm{~nm}$ 에서 흡광도를 측정하여 시 료를 처리하지 않은 well에 대한 세포 생존율을 백분율로 표시 하였다.

\section{RT-PCR}

HacaT cell에 시료를 농도별 처리하고 24시간 배양한 후에 DPBS로 3회 이상 세척 하였다. UVB $20 \mathrm{~mJ} / \mathrm{cm}^{2}$ 를 조사하고 시 험 농도로 희석된 시료와 함께 24 시간을 배양하였다. 세포를 회수한 후 RNA-bee (AMS Biotechnology (Europe) Limited. Abingdon, $\mathrm{UK}$ )로 $\mathrm{RNA}$ 를 분리하였다. RNA $5 \mu \mathrm{g}$ 정량하여 일 반적인 cDNA 합성 방법에 따라 합성하였다. PCR-pre mix kit (Bioneer, Daejeon Korea)을 사용하여 제조사의 권고에 따라 RT-PCR 실험을 수행 하였다.

\section{Western blot}

RT-PCR 시험 방법과 동일한 조건에서 세포를 배양 및 시료를 처리 하였다. 세포를 회수한 후 RIPA buffer에(Biosesang, Seongnam-si, Korea) 균질화하고 얼음에 30분간 두었다가 1.5 $\mathrm{mL}$ tube에 담아 $15,000 \mathrm{rpm}, 4{ }^{\circ} \mathrm{C}$ 에서 20 분간 원심 분리하여 상층액을 얻었다. 이 상층액에서 단백질을 정량하기 위해 Bradford Reagent (Biosesang, Seongnam-si, Korea)를 사용하였 는데 $\mathrm{BSA}$ 를 표준으로 하여 제조사가 권장하는 방법으로 실시 하여 $650 \mathrm{~nm}$ 에서 흡광도를 측정해 각 sample들의 단백질 농도 를 구하였다. 이후 각 sample당 $40 \mu \mathrm{g}$ 의 단백질을 취해 $10 \%$ $\mathrm{SDS}-\mathrm{PAGE}$ 로 $100 \mathrm{~V}$ 에서 전기 영동을 실시하고 분리된 단백질 들을 $300 \mathrm{~mA}$ 에서 2시간 동안 nitrocellulose membrane (BioRad Laboratories, CA, USA)에 옮겼다. 이후 membrane을 5\% 탈지분유와 $0.05 \%$ Tween-20을 포함하는 TBT-T 용액에 실온에 서 1시간 blocking한 후 1차 antibody (MMP-1, ERK1/2, p38, JNK, IKK, NFkb-65, GAPDH) (Santa Cruz Biotechnology, Santa Cruz, CA, USA)를 처리하고 $4{ }^{\circ} \mathrm{C}$ 에서 overnight 시켰다. 이후 TBS-T로 세척 후 anti-rabbit, anti-goat 2차 항체(Santa Cruz Biotechnology)를 1:1000으로 희석하여 실온에서 2시간 동 안 membrane과 반응시키고 세척 후 $\mathrm{ECL}$ chemiluminescence reagents (Amersham Pharmacia biotech, Bensalem, PA, USA) 로 1분간 반응시킨 후 Chemiluminesence (Vilber, Eberhardzell, Germany) 사용하여 단백질 발현양을 측정하였다. 


\section{MMP-1 단백질의 정량적 평가(ELISA)}

단백질 발현 및 유전자 발현 분석과 동일한 전처리 과정을 통 해 HacaT cell을 6-well에 $1 \times 10^{6}$ cell/well로 분주하고, 시료를 농도 별로 처리 하였다. 72시간 배양한 후에 상층액을 $1.5 \mathrm{~mL}$ tube에 담아 $15,000 \mathrm{rpm}, 4^{\circ} \mathrm{C}$ 에서 20 분간 원심분리하여 얻었다. 이후 MMP-1 (R\&D system, Minneapolis, MN, USA) ELISA kit을 이용하여 제조사의 권장 시험 방법에 따라 시료에 대한 MMP-1의 정량적 평가를 수행하였다.

\section{결과 및 고찰}

\section{$\mathrm{HaCaT}$ 에서 $\mathrm{TQE}$ 의 농도에 따른 세포 생존율 측정}

$\mathrm{TQE}$ 추출물 독성에 따른 세포 생존율을 확인하기 위하여 추출 물을 농도 별 $(10,20,50,100,200,500 \mathrm{mg} / \mathrm{mL})$ 로 처리한 결 과는 Fig. 1에 나타내었다. 그 결과 농도가 증가함에 따라 세포 생존율은 유의적으로 감소하는 경향을 보이고, $50 \mathrm{mg} / \mathrm{mL}$ 처리 시 약 $70 \%$ 정도의 생존율을 나타내었으며, 이 결과를 통해 $\mathrm{TQE}$ 추출물은 $50 \mathrm{mg} / \mathrm{mL}$ 이상으로 세포에 처리 할 경우 세포 의 생존에 영향을 줄 수 있을 것이라 판단하였다. 따라서, 세포 생존율에 영향을 미치지 않은 것으로 판단 되는 $20 \mathrm{mg} / \mathrm{mL}$ 의 농도이하에서 이후 모든 실험을 진행하였으며 추출물에 의해 피 부 활성에 미치는 효과를 확인하고자 하였다.

\section{$\mathrm{HaCaT}$ 에서 TQE 추출물이 MMP-1 발현에 미치는 효능 평가 분석}

자외선은 MMP-1의 생성을 유도하여 콜라겐의 분해 단백질의 일종인 MMP-1의 발현을 증가한다고 알려져 있다. 따라서, TQE 추출물이 자외선에 의해 유도되는 MMP-1의 생성을 억제하는 지 확인하고자 $\mathrm{HaCaT}$ 에서 RT-PCR 방법으로 MMP-1 mRNA 발현 정도를 비교 분석하였으며, 단백질의 발현 정도를 확인하 기 위하여 western blot 방법을 이용하여 검증 하였다. 또한, 발 현된 단백질의 정량을 위해 $\mathrm{HaCaT}$ 배양액만을 회수하여 MMP1 ELISA kit를 이용하여 정량하였다. TQE 추출물을 농도 별로 처리 하였을 때, TQE 추출물에 의해 MMP-1 mRNA 발현을 강하게 저해하였으며(Fig. 2A), 단백질 발현 양상도 mRNA 발 현 양상과 유사한 패턴으로 저해하는 것을 확인할 수 있었다 (Fig. 2B), 이와 같은 결과에 따라 억제된 MMP-1 단백질을 정 량하기 위해 ELISA assay 실험을 통해 MMP-1 단백질의 발현 양을 검증한 결과 역시 유전자 수준에서의 저해 양상과 유사한 결과를 확인할 수 있었다(Fig. $2 \mathrm{C}$ ). 이러한 결과를 볼때 $\mathrm{TQE}$ 추출물은 광노화 억제 소재로 유용하게 활용될 수 있을 가능성 을 확인하였다.

TQE 추출물에 대한 콜라겐 분해 효소 발현 억제 기전 분석 평가 다음으로 $\mathrm{TQE}$ 추출물의 MMP-1 발현 억제 활성에 대한 생물 학적 기전을 분석 하고자 하였다. 이미 설명한 대로 MMP-1 단 백질은 UVB 등의 자외선 자극에 따라 MEK/MAPK 신호전달 단백질의 인산화가 일어난다고 알려져 있다. 따라서, MAPK 단 백질을 대상으로 인산화 정도를 분석 하고 특정 단백질의 인산 화 저해 정도를 파악하고자 특정 단백질의 항체를 이용한 western blot을 이용하여 확인하였다. Fig. 3의 결과를 살펴보면

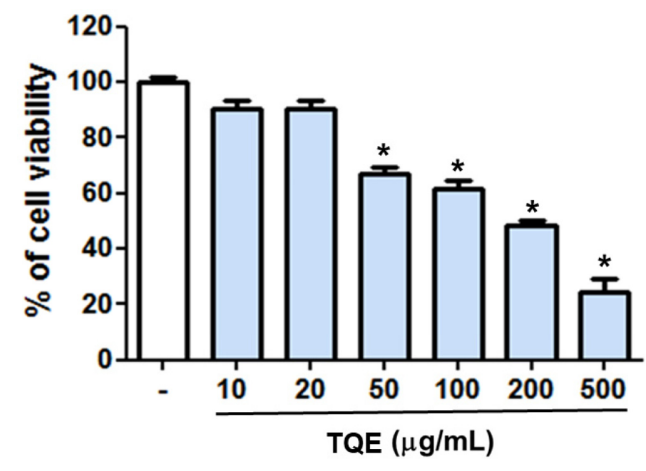

Fig. 1 Effects of Thymus quinquecostatus extract (TQE) on Cell viability in HaCaT Cells. HaCaT cells were incubated for $24 \mathrm{~h}$ at each indicated TQE concentration and the cell viability were measured by O.D. value. Viability are shown as a percentage of the negative control that was treated with medium alone. Each value represents the mean $\pm \mathrm{SD}$. ${ }^{*} p<0.05$ compared to treatment with medium alone

(A) UVB $20 \mathrm{~mJ} / \mathrm{cm}^{2}$

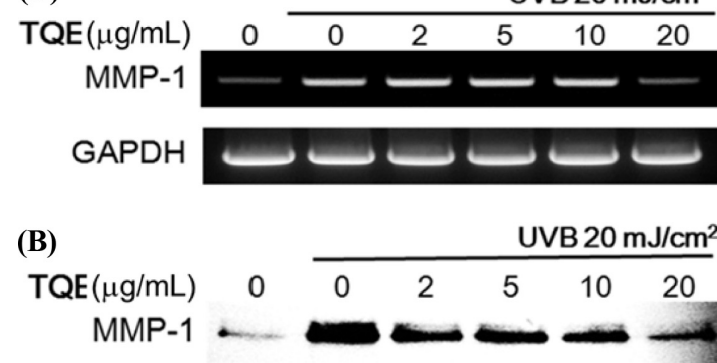

(C)

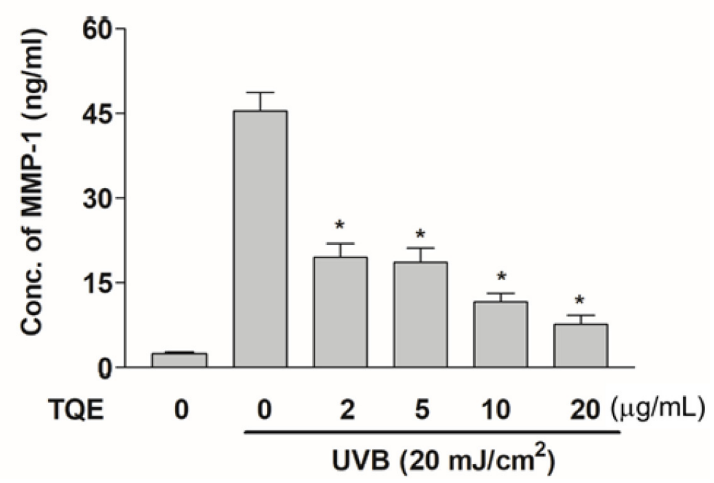

Fig. 2 Effects of TQE on MMP-1 expression in UVB-irradiated HaCaT Cells. HaCaT cells were treated with various concentration of TQE for $24 \mathrm{~h}$ and then irradiated with UVB for $20 \mathrm{~mJ} / \mathrm{cm}^{2}$. UV irradiated cells were then cultured for another 18h. The expression levels of MMP-1 mRNA were evaluated by RT-PCR. GAPDH mRNA was used as internal control (A). The expression levels of MMP-1 proteins were measured by western blot analysis (B). After TQE treatment, the expression level of MMP-1 protein was assayed by ELISA(C). Each value represents the mean $\pm \mathrm{SD} .{ }^{*} p<0.05$ compared to treatment with medium alone

자외선 자극을 주었을 때 MAPK 단백질의 인산화 정도가 증 가하는 것을 확인할 수 있었으며 $\mathrm{TQE}$ 추출물을 농도 별로 처 리하였을 때 MAPK단백질의 인산화가 저해되는 것을 확인 할 수 있었다. 이러한 결과로 $\mathrm{TQE}$ 추출물은 자외선 조사에 따른 


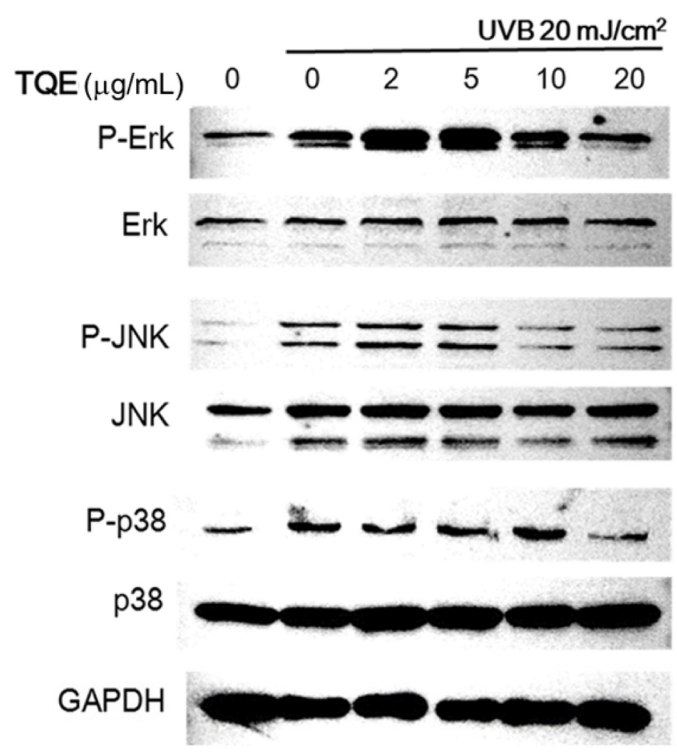

Fig. 3 Effect of TQE on phosphorylation of MAPKs in UVB-irradiated HaCaT cells. The effect of MAPKs phosphorylation levels were determined by Western blot. $\mathrm{HaCaT}$ cells were pretreated with indicated concentrations of TQE for $24 \mathrm{~h}$ and irradiated with UVB for $20 \mathrm{~mJ} / \mathrm{cm}^{2}$, and then the cells were further cultured for $30 \mathrm{~min}$. Phosphorylation of ERK, JNK, and p38 MAP kinases was determined by specific antibodies against the phosphorylated form of MAP kinases

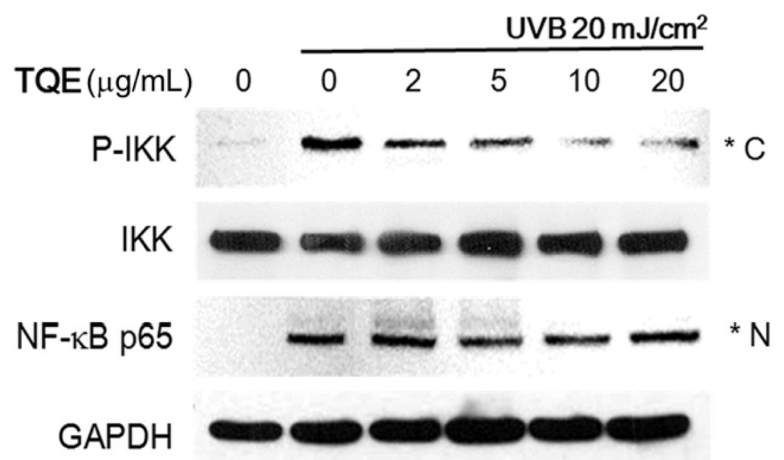

Fig. 4 Effect of TQE on phosphorylation of IKK and nucleus translocation of p65 in UVB-irradiated HaCaT cells. The effect of IKK and p65 protein levels were determined by Western blot. HaCaT cells were pretreated with indicated concentrations of TQE for $24 \mathrm{~h}$ and irradiated with UVB for $20 \mathrm{~mJ} / \mathrm{cm}^{2}$, and then the cells were further cultured for 1 h. ${ }^{*} \mathrm{C}$ : Cytosolic ${ }^{*} \mathrm{~N}$ : Nucleus

$\mathrm{MMP}-1$ 의 억제 기전에 있어 MAPK 단백질의 인산화를 억제 하는 효과가 있다는 것을 확인할 수 있었다.

\section{$\mathrm{HaCaT}$ 에서 $\mathrm{TQE}$ 추출물에 의한 IKK의 인산화 및 NF-KB 단 백질의 핵내로 이동에 미치는 영향 분석}

다음으로 MMP-1 단백질의 전사에 중요한 역할을 하는 NF-kB 단백질에 미치는 영향에 대해 조사 하고자 하였다. NF-kB 단 백질은 세포질에서 IKB 단백질과 구조적 결합을 하고 있는데 IKK 단백질의 인산화에 따라 IKB 단백질과 분리되어 핵 내로
이동한 다음 MMP-1 단백질의 전사에 관여 한다고 알려져 있 다[14,15]. 따라서 Fig. 4에서 확인하듯이 세포질에서의 IKK 인 산화는 $\mathrm{TQE}$ 의 농도 의존적으로 억제 되는 것을 확인 할 수 있었다. 반면 유리된 NF-kB 단백질의 핵 안으로 이동 저해 현 상은 아주 미약 하게 나타나는 것을 확 인 할 수 있었다. 결국 $\mathrm{TQE}$ 는 UV-B 자극에 의해 유도되는 MAPK/IKK 인산화 과정 을 효과적으로 억제 한 다는 것을 확인 할 수 있었으며, 그 결 과 MMP-1의 단백질 발현이 억제 될 것이라고 유추 해 볼 수 있다. 그러나 이를 증명 하기 위하여 MMP-1 단백질의 전사 활 성화 부분을 조사하여 실질적인 전사 억제 활성을 검증 해야 할 부분으로 생각 된다. 또한 MMP-1의 발현 증가에 따른 실 질적인 콜라겐의 분해 정도를 확인 하거나 $\mathrm{TQE}$ 에 의한 콜라겐 합성에 관한 추가 연구도 반드시 필요하다고 생각된다. 본 연 구 결과는, 사람 피부 각질 세포를 활용하여 UV-B 자극에 의 한 MMP-1발현 억제 효능을 중심으로 연구를 진행 하였고, MMP-1 mRNA 발현 억제 활성을 RT-PCR 방법으로 검증 하 였으며, 직접적인 MMP-1 단백질의 발현 억제 활성은 western 및 ELISA 실험을 통해 검증 하였다. 그 결과를 미루어 보아 $\mathrm{TQE}$ 는 아마 자외선에 의한 피부의 주름과 손상에 효과적인 기 능 소재로 활용할 수 있을 것으로 기대 된다.

\section{초 록}

자외선은 가시 광선보다 파장이 짧은 전자기파이며, 오존층을 통과하는 자외선이 피부 노화의 주요 원인이다. 피부 조직을 자 외선에 만성적으로 노출 시키면 인간 각질 형성 세포에서 Mitogen-activated Protein Kinases (MAPKs) 신호 전달 경로가 활성화되어 매트릭스 metalloproteinases (MMPs) 생성이 증가한 다. 본 연구에서는 제주도의 초본 추출물을 대상으로 자외선 자 극을 통해 인간 각질 형성 세포 $(\mathrm{HaCaTs})$ 의 항 노화 효과에 대 해 조사 하였다. 우리는 자외선 유도 된 각질 형성 세포에서 MMP-1 유전자와 단백질 발현 수준을 측정 하였으며 그 결과, Thymus quinquecostatus 추출물(TQE)은 자외선 조사된 $\mathrm{HaCaT}$ 세포에서 의해 농도 의존적으로 MMP-1의 발현을 유의하게 감 소시키는 것으로 확인되었다. 또한, $\mathrm{TQE}$ 는 $\mathrm{MAPK}$ 신호 전달 요소 인 ERK $1 / 2, \mathrm{JNK} 1 / 2$ 및 $\mathrm{p} 38$ 단백질의 자외선 유도에 따 른 인산화를 유의 적으로 감소시켰다. 이러한 결과는 MAPKs 경로가 인간 각질 세포에서 UV 유도 MMP-1 생산에 대한 $\mathrm{TQE}$ 의 억제 효과에 기여할 수 있음을 시사한다. 우리의 결과 는 아마도 인간 각질형성 세포에서 $\mathrm{TQE}$ 가 자외선 유도된 MMP-1 생산을 억제하는 피부 노화 소재로 활용될 수 있음을 시사한다.

Keywords 마이토젠 활성화 단백질 카이네이즈 · 세포외기질 금속함유 단백 분해효소 · 자외선-B · 타임 추출물 · 피부 각질 세포

감사의 글 본 연구는 산업통상자원부 지역특화산업육성사업 (R0004665) 및 경기지역협력연구센터 (GRRC-Kyunghee2018-B03) 사업의 일환으로 수 행 하였기에 이에 감사드립니다. 


\section{References}

1. Jenkins G (2002) Molecular mechanisms of skin ageing. Mech Ageing Dev 123: 801-810

2. Pittayapruek P, Meephansan J, Prapapan O, Komine M, Ohtsuki M (2016) Role of matrix metalloproteinases in photoaging and photocarcinogenesis. Int J Mol Sci 17: E868

3. Ho JH, Lee YH, Park JS, Jun WJ, Kim HK, Hong BS, Shin DH, Cho HY (2005) Protective effects of aucubin isolated from eucommia ulmoides against UVBinduced oxidative stress in human skin fibroblasts. Biol Pharm Bull 28: 1244-1248

4. Parkinson LG, Toro A, Zhao H, Brown K, Tebbutt SJ, Granville DJ (2015) Grnazyme B mediates both direct and indirect cleavage of extracellular matrix in skin after chronic low-dose ultraviolet light irradiation. Aging Cell 14: 67-77

5. McCawley LJ, Matrisian LM (2001) Matrix metalloproteinases: they are not just for matrix anymore. Curr Opin. Cell Biol 13 534-540

6. Lauer-Fields JL, Juska D, Fields GB (2002) Matrix metalloproteinases and collagen catabolism. Biopolymers 66: 19-32

7. Visse R, Nagase H (2003) Matrix metalloproteinases and tissue inhibitors of metalloproteinases. Structure, function, and biochemistry. Circ Res 92: 827-839

8. Brennan M, Bhatti H, Nerusu KC, Bhagavathula N, Kang S, Fisher GJ (2003) Matrix metalloproteinase-1 is the major collagenolytic enzyme responsible for collagen damage in UV-irradiated human skin.
Photochem Photobiol 78: 43-48

9. Reunanen N, Westermarck J, Hakkinen L, Holmstrom TH, Elo I, Eriksson JE (1998) Enhancement of fibroblast collagenase (matrix metalloproteinase-1) gene expression by ceramide is mediated by extracellular signal-regulated and stress-activated protein kinase pathways. J Biol Chem 273: 5137-5145

10. Chang L, Karin M (2001) Mammalian MAP kinase signalling cascades. Nature 410: $37-40$

11. Khan N, Syed DN, Pal HC, Mukhtar H, Afaq F (2012) Pomegranate fruit extract inhibits UVB-induced inflammation and proliferation by modulating NF-kB and MAPK signaling pathways in mouse skin. Photochem Photobiol 88: 1126-1134

12. Shin S, Kim JH (2004) Antifungal activities of essential oil from Thymus quinquecoststus and T. magnus. Planta Med 70: 1090-1092

13. Kim YS, Hwang JW, Kang SH, Kim EH, Jeon YJ, Jeong JH, Kim HR, Moon SH, Jeon BT, Park PJ (2014) Thymol from Thymus quinquecostatus Celak. protects against tert-butyl hydroperoxide-induced oxidative stress in Chang cells. J Nat Med 68: 154-162

14. Pasparakis M, Courtois G, Hafner M, Schmidt-Supprian M, Nenci A, Toksoy A, Krampert M, Goebeler M, Gillitzer R, Israel A, Krieg T, Rajewsky K, Haase I (2002) TNF-mediated inflammatory skin disease in mice with epidermisspecific deletion of IKK2, Nature 417: 861-866

15. Bell S, Degitz K, Quirling M, Jilg N, Page S, Brand K (2003) Involvement of NFkappaB signalling in skin physiology and disease, Cell Signal 15: 1-7 